\title{
57-Çeviri eğitimine yönelik yeti temelli çeviri süreci ilişkisi ${ }^{1}$
}

\section{Refika Zuhal GILIÇ²}

APA: Gılıç, R. Z. (2020). Çeviri eğitimine yönelik yeti temelli çeviri süreci ilişkisi. RumeliDE Dil ve Edebiyat Araştırmaları Dergisi, (21), 915-932. DOI: 10.29000/rumelide.843015.

\section{$\ddot{\mathbf{O} z}$}

Bu çalışmada çevirmenin baş aktör olarak deneyimlediği ve yönlendirdiği çeviri süreci ve bu süreçte devreye soktuğu yetilere değinilecektir. Ayrıca bu çalışmada çeviri eğitiminde kullanılmak üzere, çevirmen yetileri ve alt yetilerine dair kuramsal veriler eşliğinde zaman zaman bazı önermeler de yer verilecektir. Bu araştırma, üç ana bölüm ve alt başlıklarıyla tartışılacaktır. Üç ana bölüm olan kaynak metni algılama sürecindeki beceriler, hedef metni (çeviriyi) üretim sürecindeki beceriler ve erek metnin çevirmenin işvereninden ve hedef kültürden aldığı karşılı̆̆ın (dönütün) değerlendirilmesi, alt başlıklarıyla beraber irdelenecektir. Bu analizin birincil hedefi çeviri öğrencilerinde bir çevirmende bulunması beklenen yetilerin yazılı çeviri süreciyle ilişkilendirilerek aktarılmasıyla beraber, yeni çevirmen yetileri önererek çevirmen adaylarında mesleki yeti farkındalı̆̆ı oluşturmaktır. Yapılan bilgi sunusuyla söz konusu çeviri ve çevirmen yetileri hakkında bilim insanlarının ortaya koyduğu savların farklılık gösterdiği gözlemlenmektedir. Bu farklılıklar her ne kadar çeviri öğrencileri için bir zenginlik teşkil etse de, yeti bazlı çeviri sürecinin derslerde bütüncül şekilde aktarılmasının daha faydalı olacağı düşünülmektedir. Dolayısıyla bu araştırmada arka planda tutulan, hatta hiç önemsenmeyen eski ve yeni yetilere ait oldukları çeviri basamağı bağlamında değinilecektir. Sonuç olarak, bu çalışmada yazılı çeviri eğitimi için oluşturulan üç aşamalı aktif çeviri süreci ve devredeki çeviri yetileri modeli önermesiyle, yeti tabanlı çeviri eğitimine katkı sağlayacak bir ders olarak önerilebilir.

Anahtar kelimeler: Çeviri yetisi, çevirmen yetisi, çeviri süreci, çeviri eylemi, çeviri eğitimi

\section{Competency-based translation process relationship for translation education}

\begin{abstract}
In this study, the translation process experienced and guided by the translator as the main actor and the competences $\mathrm{s} /$ he activates as in this process will be mentioned. Besides, in this study, some propositions will be given place from time to time in company with the theoretical data regarding translator competences and translator sub-competences for translation education.This research will be discussed by using three main titles and sub-titles. The three main titles which are called competences in the process of source text perception, competences in the process of the production of the target text, evaluation of the feedback that the target text received from the translator's employer and target culture, will be scrutinized with their subtitles. The primary goal of this analysis is to create professional competence awareness in translation students by suggesting new translation skills, as well as transferring the translation skills that are expected to be present in a translator by associating them with the written translation process. Via the presentation of the
\end{abstract}

\footnotetext{
1 Bu makale SAÜ Çeviribilim Doktora Programında Çeviri Eğitimi dersini özveriyle gerçekleştiren Dr. Öğr. Üyesi Halil İbrahim Balkul' a ithaf edilmiştir.

2 Öğr. Gör., Sinop Üniversitesi, Ayancık Meslek Yüksekokulu (Sinop, Türkiye), refika.gilic@sinop.edu.tr; Doktora öğrencisi, Sakarya Üniversitesi, Sosyal Bilimler Enstitüsü, Çeviribilim ABD (Sakarya, Türkiye), refika.gilic@ogr.sakarya.edu.tr, ORCID ID: oooo-0003-3474-5804 [Araştırma makalesi, Makale kayıt tarihi: 17.11.2020-kabul tarihi: 17.12.2020; DOI: 10.29000/rumelide.843015]
}

Adres
Address

Istanbul Medeniyet University, Faculty of Education Sciences,

Turkish and Social Scinces Education, Turkish Language Teaching

Education, Cevizli Campus, Kartal-İstanbul /TURKEY

e-mail: editor@rumelide.com 


\begin{abstract}
information, it is observed that the arguments propounded by scientists about the aforementioned translation and translator competences differentiate. Although these differences constitute a wealth for translation students,; it is thought that it will be more beneficial to transfer the competencebased translation process in the lessons in a holistic way. Accordingly, in this study, the old and new competences that are kept in the background or even ignored at all, will be mentioned in the context of the translation step they belong to. Consequently in this study; The Three-Staged Active Translation Process and the Translation Competences Model created for the translation education can be suggested as a lesson that will contribute to competence-based translation education.
\end{abstract}

Keywords: Translation competence, translator competence, the process of translation, act of translation, translatin education (training)

\title{
1. Giriş
}

İnsanoğlunun eski zamanlardan bugüne yolcuğu baz alındığında kapanan ve açılan tarih sayfalarında yeni anlayış, yaşayış düzenine geçebilmesinde çevirinin etkin rol aldığını görmekteyiz. Bu etkin rol zamanla bu sorumluluğu gerçekleştiren kişilerin birer uzman, icra ettikleri şeyin ise eğitimle donanımı arttırılan ve uzmanlık gerektiren bir eylem olduğu kanısını yaratmıştır. Çeviri eylemini bir uzman olarak gerçekleştiren çevirmenin, bu eylemin aşamalarında kendisine ait alan eğitimi ve mesleki deneyimler vasıtasıyla geliştirdiği çeviri ya da çevirmen yetilerini uygun gördüğü noktalarda devreye sokması hem çeviri öncesi hazırlık aşamasını, hem çeviri sürecini hem de çeviri çıktısını daha kaliteli hale getirecektir. Doğal olarak bu yetileri çeviri sürecine hazırlık, çeviri süresince ve çeviri süresi sonrasını da kapsayan üç farklı aşamada ayrı ayrı kullanacaktır. Çeviri eylemi sürecini değerlendirirken ön planda yer alan bu çeviri yetileri/ yeterlilikleri/ becerileri/ edimleri ya da edinçleri diye adlandırılan mesleki gerekliliklerin çeviribilim ve alt alanlarını kapsayan literatürde birçoğu aynı kavramları dile getirse de araştırmacıların bu konuda farklı ad ve başlıklarla sıralamalar yaptı̆̆ı, var olan alt çeviri-çevirmen yetilerinin bir ya da birkaç tanesini daha çok irdeledikleri dikkat çekmektedir. Bununla birlikte, bazı araştırmacılar çeviri (ya da kimi bilim insanına göre aynı zamanda çevirmen) yetisi başlı̆̆ını bir şemsiye terim olarak adlandırmakta, farklı araştırmacılarca farklı nitelikte kategorize edilen bu alt çeviri yetilerini de bu şemsiye terimin alt başlıkları olarak konuşlandırmaktadır. Kaliteli çeviri ve çevirmen/uzman olarak çevirmeni anlamak ya da eğitebilmek amacıyla hala tazeliğini çeviribilim çalışmalarında koruyan çeviri yetisi (ÇY) konusuna dair Türkçe literatürü güncel veriler ışı̆̆ı altında incelediğimizde Akalın'ın (2016) ÇY’ yi çeviri eylemini ve eğitimini gerçekleştirebilmek için çevirmende var olması gereken bilgi ve beceri birikiminden oluşan ve birçok alt yetinin oluşturduğu bir üst yeti/edinç olarak tanımladığını görürüz. Eruz ise ÇY’yi işini icra ederken çevirmenin doğru kararlar almasına rehberlik eden bir özellik olarak tanımladığını anlamaktayız (2004: 157). Eruz aynı zamanda, Akalın'a (2016) benzer bir tutum sergileyerek ÇY' yi erek metni oluşturmak için gerekli tüm edinçleri kapsayan bir üst yeti olarak kategorize etmekte ve bu yetinin alt edinçlerini dil ve kültür edinci, metin çözümleme ve oluşturma edinci, araştırma yöntemleri ve bu süreçte uygulanması gereken yöntemleri içerdiğini ifade etmektedir (Eruz, 2003: 73,53). BirkanBaydan (2016) ise ÇY' ye dair şemsiye terim olarak "çeviri üst edinci (çeviri eyleminin ne olduğu, muhtevası, sorumlulukları, farkındalı̆̆ını kastettiğini)” dile getirmiş ve bu üst edinci kazanan çevirmenin ise yaptığı mesleği nasıl içselleştirdiği ile ilgili olan "çevirmenlik edinci” ni kavram olarak önermiştir. Ona göre çeviri üst edincinin alt alanları şunlardır; "problem çözme ve karar verme becerisi, araştırma becerisi, metin bilgisi becerisi, alan/konu bilgisi ve kültür/dil bilgisidir "(Şevik ve Gündoğdu, 2018: 78). ÇY' yi “çeviri yapabilmek için bilgi ve becerileri kullanabilmek" ve bir bakıma çevirmen adaylarının "yabancı dil ve ana dil bilinci, metin bilinci, kuramsal bilgi, kültür bilinci ve

Adres

İstanbul Medeniyet Üniversitesi, Eğitim Bilimleri Fakültesi, Türkçe ve Sosyal Bilimler Eğitimi Bölümü, Türkçe Eğitimi ABD Cevizli Kampüsü, Kartal-İstanbul/TÜRKIYY e-posta: editor@rumelide.com 
yöntem bilgisi edinmeleri” olarak tanımlayan Şevik ve Gündoğdu (2018) ise çalışmalarında BirkanBaydan'ın (2016) gündeme getirdiği bu çeviri üst edinci ve alt sınıflandırmalarına değinmişlerdir. Türkçe literatüründeki verilere benzer olarak küresel çalışmalara bakacak olursak çeviriyi dilbilim içerisinde dil bilim uygulamalarıyla gelişen bir alt alan olarak değerlendiren Neubert (2000: 6) ÇY’ yi dil edinci, metin edinci, konu alanı edinci, kültür edinci, aktarım edinci olmak üzere beş temel bileşenle açıklamıştır. Kautz (2002: 20) ise ileride uzman olarak çevirmenlik görevini yapacak adaylara mesleği icra etmeye başlamadan önce edinilmesi gereken beceri ve yetenekleri şu şekilde siralamaktadır:

"1. Çevirmenin sahip olduğu dünya bilgisi,

2. Sürekli olarak değişen ve gelişen ana dil ve kültür bilinci, yani ana dil edinci,

3. Sürekli değişen ve gelişen yabancı dil ve kültür bilgisi, yani yabancı dil edinci,

4. Çeviribilime ait kuram ve yöntem bilgisi,

5. Kaynak metni analiz yetisi, çeviri stratejileri belirleme, erek metin üretimi, erek metin edimi, çeviribilimin terminoloji bilgisi, kısacası çeviri edinci,

6. Çeviri mesleği uygulaması üzerine bilgi ” (Aktaran Şevik \& Gündoğdu, 2018: 84).

Albir (2007) ise çeviri eğitiminde yeti temelli müfredat dizaynını ele aldığı çalışmasında bilim insanlarının ÇY diye adlandırılabilecek bu üst terimin bileşenleri olan alt yetilerin sadece bazılarına değinen modeller sunmasından yakınmakta, Delisle, ise Albir ile paralel olarak çeviri kuramlarını eksik yönlerinden dolayı reddederek bu kuramların çeviri mekanizmalarını aydınlatmada yetersiz oldukları sonucuna varmıştır. Delisle (2001), söylem çözümlemesi üzerine kurguladı̆̆ı akademik çeviri eğitimine yönelik seminerlerin/derslerin amaçlarına geçmeden önce çeviri ediminin eksik yorumlandığını iddia ettiği kavramlarla ilgili bir çözümleme önermiştir; onun verdiği başlıklar doğrultusunda ÇY şu başlıklardan oluşmaktadır:

\begin{abstract}
"Ortaya atılan modellerin çoğu Çeviri Yetisini (ÇY) oluşturan bileşenleri tanımlamaya odaklanmıştır. Bu durum Lowe (1987), Bell (1991), Hewson ve Martin (1991), Nord (1991, 1992), Pym (1992), Kiraly (1995), Presas (1996), Hurtado Albir (1996), Hatim ve Mason (1997), Hansen (1997), Risku (1998), Neubert (2000), Kelly (2002) ve Gonçalves (2003, 2005) için yetilerin birkaçını tanımlama açısından geçerlidir. Aynı zamanda yabancı bir dile çevirinin karakteristik özellikleriyle ile ilgili olan ters çeviri için Çeviri Yetileri (ÇY) ile alakalı bazı özel çeviri katkılar da bulunmaktadır (Beeby 1996, Campbell 1998, Martinez Mélis 2001)” (Aktaran Göktaş, 2014: 54, Delisle, 2001).
\end{abstract}

$\mathrm{Bu}$ doğrultuda PACTE (Process of the Acquisition of Translation Competence and Evaluation/ ÇY Kazanımı ve Değerlendirilmesi Süreci) adını verdikleri, ÇY ve kazanımı üzerine deneysel incelemeler yapan (Beeby, Berenguer, Ensinger, Fox, Hurtado Albir, Martinez Melis, Neunzig, Orozco and Presas adlı bilim insanlarının oluşturduğu) araştırma grubu ÇY’ye adeta kılavuzluk eden hipotezlere imza atmaktadır. PACTE çalışmalarını gerçekleştiren araştırmacılar ÇY'yi alt kategorilere ayırarak daha bütüncül, mantıklı bir model önermektedir (PACTE, 1998, 2000). Onlara göre ÇY çeviri yapabilmek için gerekli olan bilgi, doğuştan gelen kabiliyet ve yetilerin temelini oluşturduğu bir sistemdir ve iki dile ait iletişimsel yeti, dil dışı yeti, aktarım yetisi, araçsal/mesleki yeti, psikofizyolojik yeti (psikomotor, bilişsel ve davranışsal yetilerin bütünü) ve stratejik yeti olmak üzere altı alt yetiden oluşmaktadır (Martinez Melis and Amparo Hurtado, 2001: 280). Zainurrahman (2010) ise PACTE çalışmalarını sürdüren bir dizi bilim insanından farklı olarak yetilerini beşe ayırmıştır; dil yetisi, metinsel yeti, konu yetisi, kültür yetisi ve aktarım yetisidir. Yapılan bu çeşitli yeti bazlı sınıflamalar her ne şekilde olursa olsun, çeviri eğitimine ve kazanımlarına ilgili sınıf veya seviyelerine paralel biçimde entegre edildiğinde, çeviribilim öğrencileri üstünde istendik davranış değişiklikleri ve mesleki

Adres

İstanbul Medeniyet Üniversitesi, Eğitim Bilimleri Fakültesi, Türkçe ve Sosyal Bilimler Eğitimi Bölümü, Türkçe Eğitimi ABD Cevizli Kampüsü, Kartal-İstanbul/TÜRKIYE e-posta: editor@rumelide.com
Address

Istanbul Medeniyet University, Faculty of Education Sciences,

Turkish and Social Scinces Education, Turkish Language Teaching

Education, Cevizli Campus, Kartal-İstanbul /TURKEY

e-mail: editor@rumelide.com 
donanım kazanımları en yüksek seviyede elde edilebilecek; bu durum ise eğitim çıktısı (süreç ve kazanım bakımından) ve eğitimi alan çevirmen adaylarını kalite konusunda olumlu yönde etkileyecektir.

\section{Metodoloji}

Yukarıda örneklendirilen tüm yerli ve yabancı çeviribilimcinin yapmış olduğu analizlerden yabancı dil eğitimi almış ya da doğal olarak iki ya da üç ana dilli her kişinin çevirmenlik mesleğini icra etmesinin söz konusu olamayacağı anlaşlmaktadır. Bir çevirmen yabancı dil/ler bilmekle beraber birçok karmaşık bilişsel, psikomotor, psikososyal aşamalarda bu dilleri hedef kültürde (HK' de), aktif şekilde, özel yetilerle beraber süreçlendirebilmektedir. Bu çalışmada, çeviri sürecinin bel kemiğini oluşturan ÇY’ ye dair Üç Aşamalı Aktif Çeviri Süreci ve Devredeki Çeviri Yetileri adıyla bir model önererek üçe ayırdığımız çeviri süreci ve paralelinde çevirmenin başvurabileceği ÇY’leri bir veri derlemesi ve tartışması olarak sunulacak ve yeti bazlı çeviri eğitiminde kullanılması muhtemel bir ders olarak önerilecektir. İlk ana başlık kaynak metni (KM) algılama sürecindeki beceriler ve ilk alt başlığı olan KM anlama ve bu başlığın alt başlığı olan dil edinci bununla ilişkili olan iletişimsel edincin aktarılmasıyla başlayacaktır. İlk ana başlı̆̆ın geri kalan beş alt başlığı ise sırasıyla; çeviri odaklı KM türünü belirleme, çeviri öncesi metin analizi yapma, sözlük ve internet kullanımı, uzmanlara danışma, paralel (koşut) metin ve alanla ilgili metinlerin analizidir. İkinci ana başlıkta hedef metni (HM) üretim sürecindeki beceriler ve alt başlıkları olan; KM ve erek alıcının (yapısal ve kültürel) taslağını oluşturma, erek metnin oluşturulması, çeviri hatalarının ve süreçlerinin gözden geçirilmesi, erek metnin düzeltilmesi ve de en son erek metnin yapısal olarak gözden geçirilmesi irdelenecektir. Üçüncü ana başlıkta ise erek metnin işveren, alıcı ve HK' de bulduğu karşılığın değerlendirilmesi.

\section{Kaynak metni algılama sürecindeki beceriler}

Her çeviri eyleminde baş aktör olan çevirmen, aldı ̆̆ı eğitim ve tecrübelerinin gereği olarak içinde barındırdığı yetiler bütünü olan ÇY ile kendisine gelen sorumluluğu tamamlamak için işe koyulur. Bu sürecin ilk adımı elindeki metni algılama/anlama sürecidir. Bu da doğal olarak metinsel yetinin çevirmen tarafından kullanılmaya başlamasıyla gerçekleşecektir. Metinsel yeti en net haliyle bağlaşıklık ve retorik örgüsüyle bir metin oluşturma kurallarını içermektedir. Bachman (1990) bağlaşıklığı gönderim değiştirme, eksiltili yapılar ve sözcük uyumu gibi anlambilimsel ilişkilerin açık bir biçimde ifade edilmesi olarak tanımlamıştır. Çeviriye özgü metinsel edinç ise ilgili dilbilimsel ilkelerin anlaşılması ve bunların erek dil normlarına uygun bir biçimde hedef dilde (HD' de) oluşturulması olarak tanımlanabilir (Kansu- Yetkiner, 2009: 41).

\subsection{Kaynak metni anlama}

Anlamaya geçmeden önce anlam nedir diye sorgulayacak olursak, TDK Sözlüğüne göre; bir sözden, bir davranış veya olgudan anlaşılan şey, bunların hatırlattığı düşünce veya nesne, mana, meal” (http://www.tdk.gov.tr, Genel Türkçe Sözlük) sonucuna ulaşırız. Vardar'ın Açılamalı Dilbilim Terimleri Sözlüğüne göre ise anlam; "dildeki bir birimin aktardığı ya da uyandırdığg kavram, tasarım, düşünce; içeriktir” (2007: 19). Ferdinand de Saussure' ün yapmış olduğu anlam tanımlaması ise tümce ile sınırlı kalmakta, ancak arkasından gelip anlamın tanımına söylem, bağlam, durum, biçim, töz vs. kavramlarını katan bilim adamlarının önünü büyük ölçüde açmaktadır (Aslan Karakul, 2015: 68). Çeviri eyleminin ilk basamağını oluşturan anlama ile ilgili Köktürk ve Çoban (2011: 79) anlama olgusunun çevirmenin anahtarı olduğuna işaret ederek çevirmenin başarılı bir çeviri süreci

\footnotetext{
Adres $\mid$ Address

İstanbul Medeniyet Üniversitesi, Eğitim Bilimleri Fakültesi, Türkçe İstanbul Medeniyet University, Faculty of Education Sciences, ve Sosyal Bilimler Eğitimi Bölümü, Türkce Eğitimi ABD Cevizli Turkish and Social Scinces Education, Turkish Language Teaching Kampüsü, Kartal-İstanbul/TÜRKIYE $\quad$ Education, Cevizli Campus, Kartal-İstanbul /TURKEY e-posta: editor@rumelide.com $\mid$ e-mail: editor@rumelide.com
} 
deneyimleyebilmesinin ön koşulu olduğunu da ifade etmektedirler. Köktürk ve Çoban (2011: 81) diğer önemli noktanın ise çevirmenin her yazı herkes anlasın diye yazılmadığının farkında olması, yazarı anlamak için onunla ortak bir payda da buluşması gerektiği, bu buluşmayı sağlamak için de çevirmenin sahip olması gereken yetilerin konu, alan, genel kültür, dünya bilgisi vb. gibi beceriler olmasıdır diye sıralamaktadır. Anlama ve algılamayla ilgili çevirmenin içerisine girdiği bu bilişsel sürecin çeviribilim alanında ön plana çlkmasında Seleskovitch ve Lederer'in birlikte geliştirdiği Yorumlayıcı Çeviri (Anlam) Kuramı / (YÇK) (Göktaş, 2014: 46) büyük önem arz etmektedir. YÇK çeviri eyleminde merkeze aldığı çevirmenin çeviri etkinliği vuku bulurken zihninin işleyişine odaklanarak anlamı algılayabilme ve sonrasında HD' de ifade edebilmede dil ile düşünce arasındaki dinamik süreci keşfetmeye çalışır. YÇK’ ya göre anlam, bir söylem ya da metin parçasının dilsel anlamı ile çevirmenin o anda devreye giren dünya bilgisinin sentezinin ürünüdür. Anlam, çevirmen metnin ve söylemin mesajını çıarmaya çalışırken ulaştığı farklı türlerdeki anlam birimleridir/unité de sens (Lederer, 1981). YÇK' ye göre çeviri ürününün başarılı olması, anlamın öznesi olan çevirmenin KM' de ifade edilen anlamı, kaynak dil (KD) açısından anlamsal eşdeğerliği, erek dil açısından biçimsel eşdeğerliği sağlamasına bağlıdır (Lederer, 1981). Buna göre anlama ve anlam kavramları ve içerikleri açıklanmaya muhtaç nesneler haline dönüşmektedir. Delisle (2001: 88) anlama olgusunu bir yeti, dille ifade edebilme yetisi ve bir tasarım olarak görmektedir. Anlama yetisi beraberinde yorumlama yetisini getirecektir ki çevirmen çevireceği metni doğru şekilde ele alsın ve sentezleyebilsin. Bu durumda da çevirmenin öne çıkan rolü adeta açılmaya muhtaç kapalı bir sandık gibi beklemektedir. Benzer olarak Lederer (1981: 46) ve göstergebilim uzmanı Lyudscanov (Aktaran Delisle 1982: 51-52) da "çevirmen bir araştırma nesnesi "olarak incelendiği takdirde çevirinin bir süreç olarak tüm yönleriyle açıklı̆ga kavuşturulabileceğini varsaymaktadır.

\subsubsection{Dil yetisi: anadil- hedef/ erek dil yetisi ve iletişimsel yeti}

Çevirmenin çeviri eylemine başladığı bilişsel noktada KM' yi algılamak için öncelikle hayatı algılayıp anlamlandırdığı hatta yabancı bir dilin dil bilgisel, edim bilimsel, psiko-dilbilimsel, sözcük bilimsel, cümle bilimsel, anlam bilimsel vb. bileşenlerini tanıyabilmek için anadil yetisini devreye sokacağı su götürmez bir gerçektir. Sonuçta bir insan hangi yaş ve meslek gurubundan olursa olsun iç ve dış dünyayı kendi anadiliyle öğrenir ve benimser. Bu da yapacağı her işte öncelikle beyninde anadiliyle oluşan şemaları kullanacağı anlamına gelmektedir. Yani çevirmen okuduğu ve çevireceği KM anlama ve algılama sürecinde kendi anadilinin kodlarıyla okuma-incelemesini yapabilecektir. Çeviri yetileri ve çevirmenin bilişsel süreçlerini inceleyen bilim insanları çevirmenin KM algılamasında kullandığı bu dilsel yetiyi hep HD yetisiyle aynı bağlamda tutmuştur. Aslında çevirmenin yetkin olduğu dil çiftlerinin de ilkinin her zaman ana dili olamayacağı durumlarda dahi bilişsel dünyasında psikomotor olarak eyleme dönüşmeden önceki zihinsel faaliyetlerinin anadilinin hâkimiyeti altında ilerlediğini bilmekteyiz. Bu açıdan derleme çalışmamızda bahsettiğimiz KD için her zaman anadilimizi kastetmediğimizi hatırlatma fayda görmekte çeviride çevrilecek KM algılama sürecinin anadilde anlamlandırma aracı olan anadil yetisinin devreye sokulmasıyla başladığını belirtmekteyiz.

Aktive edilen çevirmenin zihni anadiliyle KM algılamaya başladıktan sonra "anlamı dil bilgisel biçiminden sıyırmak ve anlaşılan anlamları ve metnin uyandırdı̆̆ duyguları öteki dilde ifade etmek" (Lederer, 1994: 11) aşamasına geçmek ister. Bunu daha az kayıpla yaşamadan yapabilmesi için; "bir çevirmenin hem kaynak dilin hem de amaç dilin işleyiş düzenini çok iyi bilmesi, ikisinde de dil bilgisel öğeleri çözümleyebilecek yetide olması elbette gerekmektedir" (Durmuşoğlu, 1987: 60). Bu noktada bir başka dilde KM yeniden oluşturma sürecinde HD edinci ile Bachman 'ın dil edinci modelini çeviri çalışmalarına uygulayan Cao $(1997,2007)$ 'dan bahsetme fayda görmekteyiz. Çünkü Cao (2007)

Adres

İstanbul Medeniyet Üniversitesi, Eğitim Bilimleri Fakültesi, Türkçe ve Sosyal Bilimler Eğitimi Bölümü, Türkçe Eğitimi ABD Cevizli Kampüsü, Kartal-İstanbul/TÜRKIYE e-posta: editor@rumelide.com
Address

İstanbul Medeniyet University, Faculty of Education Sciences,

Turkish and Social Scinces Education, Turkish Language Teaching

Education, Cevizli Campus, Kartal-İstanbul /TURKEY

e-mail: editor@rumelide.com 
Bachman' ın dil edinci modelinden esinlenerek farklı bir çeviri edinci modeli öne sürmüştür; üç parçalı ve parçaların aktif etkileşim halinde olduğu bu modele göre; çeviriye yönelik dil edinci, çeviriye yönelik bilgi yapıları, çeviriye yönelik stratejik yeti, çeviri edincini oluşturan bileşenlerdir. Çeviri sürecinde çevirmenin dilbilgisel edinci hem $\mathrm{KD}$ hem de erek dilde anlamlı tümceler oluşturmasını sağlayan sözdizimsel, sözcükbilimsel, anlambilimsel kurallara ilişkin yetkin bir bilgi birikimini ifade etmektedir. Metinsel edinç ise bağlaşıklık ve bağdaşıklık gibi olgularla metin oluşturma kurallarını içermektedir. Çevirmen, anadil edinci ile yaptıklarını bu sefer HDde gerçekleştirecektir. Bu durumda da "yabancı dil yetisi ile anadili yetisine sahip olmanın ÇYne sahip olmanın vazgeçilmez unsuru" olduğunu bir kez daha görmekteyiz (Durukan, 2016: 47). HD ulaştığı yetkinlikle yapacağı bu yeniden anlamlandırma sürecinde çevirmenin devreye sokacağı yeti çok boyutlu iletişimsel yetidir. Kökeni çok eskilere dayanan iletişimsel yeti ya da edinç kavramı ise sosyolog ve antrapolog Hymes (1972) tarafından bulunmuş ve Chomsky'nin (1965) dar çerçeveli olduğunu düşündüğü dil edinci tanımına çok boyutlu bir yanıt sunmayı hedeflemiştir. Hymes' e göre iletişimsel yeti çevirmende çeviri yapabilmek için var olan bilgilere ve kapasiteye sahip olmanın yanında, bu bilgiyi uygun uzam ve zamanda kullanabilmedir. Canale ve Swain (1980) ise iletişimsel yetinin edimbilim ve söylem edinciyle olan dolaylı organik bağına değinmiş, Canale (1983) bu bakış açısını geliştirerek iletişimsel yeti ile ilgili dört bölümden oluşan bir kuramsal çerçeve önermiştir. Bu çerçevede iletişimsel yetinin içerdiği alt yetiler; dilbilimsel yeti (kelime ve cümle hâkimiyeti ve kullanım bilgisi, sentaktik, semantik, fonotik bilgi), toplum dilbilimsel yeti (dil kullanımı tercihleri), söylem yetisi (bağdaşıklık ve bağlaşıklık bilgisi) ve stratejik yeti (iletişimi sağlıklı kurabilmek için devreye sokulan her türlü metod ve strateji bütünü) dür (Aktaran Çetin, 2017: 185, Celce-Murica, Dörnyei ve Thurell, 1995:7).

\section{2. Çeviri odaklı kaynak metnin türünü belirleme}

Çeviri odaklı KM türünü belirleme şüphesiz ki çevirmenin KM'yi algılayıp, alımlanmasından sonra yapması gereken ve çeviri sürecinde işini en çok kolaylaştıracak olaylardan bir tanesidir. Çevirmenden metin türleri, kaynak ve erek dilde uzmanlık, alan ve konu bilgisi, dünya ve kültür bilgisine sahip olması ve önüne konulan metni bir uzman olarak incelemesi beklenmektedir (Köktürk ve Çoban, 2011: 87). Çevirmende bu bilişsel süreçte hafızasına mesleki eğitim ve deneyimleriyle kaydedilen bilgileri kullanmakta, okuma anlama sürecinde dilbilimsel ve zihinsel süreçler etkileşim halinde işleyiş göstermektedir. Bu etkileşimle metnin anlamı ortaya çıkar ve metnin türüyle ilgili ipuçlarına ulaşabilir. KM' nin tamamı bilişsel olarak irdelendiğinde algılama süreci gerçekleşir ve hafızasında kavramsal, yapısal çerçeve oluşan çevirmen, artık metnin türünü saptamak için girişimlerde bulunacaktır. Çeviri aşamasına geçmeden önce yapılacak KM türünü belirleme; bu yönde metnin dilbilimsel, bağlamsal, söylemsel çözümlemesini yapmak çevirmenin sadece işini kolaylaştırmayacak, aynı zamanda sağlıklı bir çeviri sürecinin temellerini atmasını sağlayacaktır. Metnin türü neyse terminoloji ve oluşturulacak erek metin bağlamı ve yapısı bu türe göre oluşturulacaktır. Bu bölümde daha çok Tülek' in (2017) hazırladığı Çeviride Ortamın Görünümleri: Metin Türlerinin Dönüşümü adlı çeviribilimde her metnin bir işlevi ve bu işlevin ilk amaçlanandan farklı olabileceği, kitlesel okur algısıyla bu farkın oluştuğunu, bunun da kitlesel okur algısının ortam tarafından şekillenmesiyle gerçekleştiğinden ve uygulamalı çeviribilim çalışmalarında ortam uzmanlığının bir alt çeviri edinci olarak yerleşmesinin önerisinde bulunduğu doktora çalışmasından faydalanılacaktır. Tülek, çeviride metinlerin diğer metinlerle ilgisinin yanında türlerinin de ele alınmasının her biri farklı amaca hizmet ettiği için hayati olduğunu belirttiği çalışmasında metin türü ayrımına ilk kez Schleiermacher' in 19. yüzyılın başında yaptığını dile getirmiştir $(2017: 17,18)$. Schleiermacher "ticari ve yasal metinlerin" çevirisini yapan kimselere "dilmaç", "bilimsel ve sanatsal metinlerin" çevirisini yapan kişilere ise çevirmen demiştir (Yazıcı, 2010:73). Ancak metnin türüne göre farklı çeviri yaklaşımlarının (dini metinler için kaynak odaklı,

Adres

İstanbul Medeniyet Üniversitesi, Eğitim Bilimleri Fakültesi, Türkçe ve Sosyal Bilimler Eğitimi Bölümü, Türkce Eğitimi ABD Cevizli Kampüsü, Kartal-İstanbul/TÜRKIYE e-posta: editor@rumelide.com
Address

İstanbul Medeniyet University, Faculty of Education Sciences,

Turkish and Social Scinces Education, Turkish Language Teaching

Education, Cevizli Campus, Kartal-İstanbul /TURKEY

e-mail: editor@rumelide.com 
dünyevi metinler için erek odaklı) benimsenmesi gerektiği çok daha eskilere, Cicero'ya (ì.Ö. 1. yy) dayanmaktadır (Eruz, 2000:36, Yücel, 2016:185, aktaran Tülek, 2017:18). Yazıcı'nın (2010: 88) aktardığına göre Koller, çeviride eşdeğerliliği metin çözümlemesinin yönlendireceğini savunmaktadır. Koller, metin çözümlemesinde eşdeğerlik evrelerini düzanlamsal, yananlamsal, metinsel, edimsel ve biçimsel eşdeğerlik olarak sıralamış ve çeviri amaçlı metin çözümlemesinde kullanılacak yönteme çevirmenin karar vereceğini belirtmiştir. Koller’in, çeviri amaçlı metin çözümlemesi bağlamında metindışı öğelere ve edimsel eşdeğerliğe yer vermesi, çeviride devingen ilişkilerin öne çıkarılması bakımından önemlidir (Tülek, 2017: 18). Reiss ve Vermeer (2014: 17) ise çeviri eyleminin daima önceden üretilmiş bir KM ve başka bir kültür için bir HM üretimini içerdiğini, bu nedenle bir metin üretim kuramının, bir çeviri eylemi kuramının geliştirilme için ön koşul oluşturduğunu ileri sürmektedir (Aktaran Tülek, 2017: 18).

Modern anlamda inceleyecek olursak Katherina Reiss çeviride metin türü kavramının önemini ilk 1980'lerin başlarında gündeme getiren ve metin türüne göre ilişkileri inceleyerek metinleri sınıflandıran ilk çeviribilimcidir. Metin türlerini bilgilendirici, yazınsal, işlemsel/işlevsel ve görselişitsel olarak sınıflandırmıştır. Metin türünü sözcük dağarcığı seçimi, dilbilgisel ve biçemsel öğeler gibi diliçi öğeler ile erek metnin durum, zaman, yer, alıcı ve göndericiyle ilişkileri gibi dildışı öğelerin belirlediğini anlatmıştır (Yazıcı, 2010: 142-143, Aktaran Tülek, 2017:19). Reiss, çevirinin işlevselliği açısından amaçlı bir eylem olduğunu ve metnin erek ekindeki işlevine göre amacın değiştiğini söylemektedir. Benzer olarak Hölz-Manttari de çeviriye ilişkin eylem kuramında bir amaç doğrultusunda üretilen her tür metni çeviriye ilişkin eylem kuramına dâhil etmekte, Vermeer ise metnin bir amaç doğrultusunda üretilmesi (texteme) ile eylem son bulmayacağını, bunun erek okuyucuya ulaşarak yeni bir eylem başlatmasıyla, yani translatum (okuyucuya ulaşmış çeviri yapitı) haline gelmesiyle son bulacağını savunur. Nord ise, iki kişi arasında yerine getirilen eylemin amacına ulaşmasında karşılıklı etkileşimin kaçınılmaz olduğunu (Nord, 1997: 16, Yazıcı, 2010: 144) belirtmiştir, yani Nord'a göre çeviri eylemi, çeviri yapıtın oluşturulmasıyla son bulmamakta, erekte amaçlanan eylemin başlatılmasıyla son bulmaktadır. Nord ayrıca çeviri amaçlı metin çözümlemesinde kullanılan ölçütlere amaç, hedef kitle ve yayın nedeninin yanı sıra yayın yeri ve zamanını ekleyerek çeviride ortama yönelik farkındalık göstermiştir. (Yazıcı, 2010: 167, aktaran Tülek, 2017:19). Eruz ise bu bağlamda kullanmalık metinler ile yazınsal metinleri dilin kullanımı bakımından ayırmakta, kullanmalık metinlerde dilin araç, yazınsal metinlerde ise amaç olduğunu belirtmektedir (Eruz, 2000: 47). "Aslında dil tüm metinlerde bir araçtır", Eruz' un bu ifadeyle kastettiği, yazınsal metinlerin yazar kaynaklı, "konusunu kendi varlığından yola çıkarak oluşturan" metinler olduğu, kullanmalık metinlerin ise "bir soruna çözüm aramak için üretilen metinler" olduğudur (Rolf, 1993, Aktaran Eruz 2000: 47).

Aşağıda Tülek' in (2017) çeviribilimcilerin ortaya attığı metin çözümleme ilke ve modellerinden faydalanılarak oluşturduğu tablolardan çevirmenlerin hangi tür metinleri hangi prensip ve yapılandırmayla dolayısıyla hangi yetilerini devreye sokarak oluşturabileceklerine dair bilgiler edinmek amaçlanmaktadır. Rolf, Werlich' ten yaptığı bir alıntıyla metinleri aşağıdaki gibi sinıflandırmaktadır (Aktaran Eruz, 2000: 41).

\footnotetext{
Adres $\mid$ Address

İstanbul Medeniyet Üniversitesi, Eğitim Bilimleri Fakültesi, Türkçe İstanbul Medeniyet University, Faculty of Education Sciences, ve Sosyal Bilimler Eğitimi Bölümü, Türkçe Eğitimi ABD Cevizli Turkish and Social Scinces Education, Turkish Language Teaching Kampüsü, Kartal-İstanbul/TÜRKIYE $\quad$ Education, Cevizli Campus, Kartal-İstanbul /TURKEY e-posta: editor@rumelide.com 1 e-mail: editor@rumelide.com
} 
Tablo 1: Rolfa göre metin sinıflandırması (Tülek, 2017:20):

Metin tipi Metin biçimi

\begin{tabular}{|l|l|l|}
\hline Betimleyici & $\begin{array}{l}\text { Öznel } \\
\text { İçedönük betimleme }\end{array}$ & $\begin{array}{l}\text { Nesnel } \\
\text { Teknik betimleme }\end{array}$ \\
\hline Anlatıcı & Anlatı, öykü & Rapor \\
\hline Sergileme & Kompozisyon & Tanımlama, Özet, Metin Yorumu \\
\hline Gerekçelendirme & Yorum & Bilimsel çalışmalar \\
\hline Buyurgan & Talimat & Kural, Yönerge, Yasa \\
\hline
\end{tabular}

Reiss (2000:163-166), metin çözümlemesinin şu üç aşamadan oluştuğunu iddia etmektedir. Bunlar ise: (1) metin türünün (bilgilendirici, yazınsal-sanatsal, işlevsel) belirlenmesi; (2) metin çeşidinin (masal, ölüm ilamı, reçete vb.) belirlenmesi, (3) üslup analizi. Reiss'ın metin sınıflandırmasını temel alarak Yazıcı'nın (2010: 143) metin türlerini aşağıdaki tablodaki gibi göre sınıflandırdığı görülmektedir.

Tablo 2: Metin Türleri (Tülek, 2017: 22, 23)

\begin{tabular}{|c|c|c|c|c|}
\hline $\begin{array}{l}\text { Metin } \\
\text { Türü }\end{array}$ & Bilgilendirici metin & $\begin{array}{l}\text { Yazınsal } \\
\text { metin }\end{array}$ & $\begin{array}{l}\text { İşlemsel/işlevsel } \\
\text { metin }\end{array}$ & Görsel ve işitsel metin \\
\hline Dil & $\begin{array}{l}\text { Düz yazı } \\
\text { (örn. } \\
\text { Ansiklopedi maddesi) }\end{array}$ & $\begin{array}{l}\text { Söz } \\
\text { sanatları } \\
\text { içeren } \\
\text { yazınsal } \\
\text { dil (örn. } \\
\text { roman) }\end{array}$ & $\begin{array}{l}\text { Söyleşisel (örn. } \\
\text { banka } \\
\text { hesapbildirim } \\
\text { formu) }\end{array}$ & $\begin{array}{l}\text { Görsel-işitsel malzeme yanı sıra } \\
\text { söyleşisel dil (Örn. Reklamlar, seçim } \\
\text { konuşması) }\end{array}$ \\
\hline \multirow[t]{2}{*}{ Odak } & İçerik odaklı & $\begin{array}{l}\text { Biçim } \\
\text { odaklı }\end{array}$ & Çağrı odaklı & İçerik + biçim + çağrı + görsel \\
\hline & & & & l, işitsel malzeme odaklı \\
\hline \multicolumn{5}{|c|}{$\begin{array}{l}\text { Kaynak metin türünün çeviri metne yansıması (kaynak ve metin türü } \\
\text { İlişkisi) }\end{array}$} \\
\hline $\begin{array}{l}\text { Çeviri metnin } \\
\text { hedefi }\end{array}$ & $\begin{array}{l}\text { Bilgi aktarım (Nesne } \\
\text { veya kavramsal } \\
\text { düzlemde göndergesel } \\
\text { içeriğin aktarımı) }\end{array}$ & $\begin{array}{l}\text { Yazınsal } \\
\text { biçemin } \\
\text { aktarımı }\end{array}$ & Tepki yaratma & Tepki yaratma \\
\hline $\begin{array}{l}\text { Çeviri } \\
\text { yöntemi }\end{array}$ & Erek odaklı & $\begin{array}{l}\text { Kaynak } \\
\text { odaklı }\end{array}$ & $\begin{array}{l}\text { Erek odaklı } \\
\text { (uyarlama) }\end{array}$ & Erek odaklı (uyarlama) \\
\hline
\end{tabular}

Tablo 3: Nord’un işlevsel kuram yorumlamasına göre metin çözümlemesi (Tülek, 2017: 23):

\begin{tabular}{|l|l|}
\hline Çeviri Yönergesi & $\begin{array}{l}\text { (örn. Bir ilaç prospektüsünü internet ortamında her kesim } \\
\text { hastaya seslenecek şekilde çeviriniz.) }\end{array}$ \\
\hline Çeviri metnin işlevi (amacı) & Bilgi ve çağrı \\
\hline
\end{tabular}

\footnotetext{
\begin{tabular}{r|l} 
Adres & $\begin{array}{l}\text { Address } \\
\text { İstanbul Medeniyet Üniversitesi, Eğitim Bilimleri Fakültesi, Türkçe }\end{array}$ \\
İstanbul Medeniyet University, Faculty of Education Sciences,
\end{tabular} ve Sosyal Bilimler Eğitimi Bölümü, Türkce Eğitimi ABD Cevizli Turkish and Social Scinces Education, Turkish Language Teaching Kampüsü, Kartal-İstanbul/TÜRKIYY $\quad$ Education, Cevizli Campus, Kartal-İstanbul /TURKEY e-posta: editor@rumelide.com 1 e-mail: editor@rumelide.com
} 


\begin{tabular}{|l|l|}
\hline Hedef kitle & $\begin{array}{l}\text { İnternet kullanabilen genellikle en az lise düzeyi orta yaş migren } \\
\text { hastaları }\end{array}$ \\
\hline Yayın yeri & İnternette Türk ilaç rehberi adlı site \\
\hline Yayın yılı & 2004 \\
\hline Yayınlanma nedeni & $\begin{array}{l}\text { Öteki ağrı giderici ilaçlardan farklı olarak migren hastaları için } \\
\text { özel hazırlanmış "İmigran" adlı ilacı tanıtmak }\end{array}$ \\
\hline
\end{tabular}

Yazıcı'nın (2010:183) yukarıda belirtilen kuramlar ışığında betimleyici kurama dayalı bir analiz modeli geliştirerek bunu aşağıdaki gibi tablolaştırdığı görülmektedir:

Tablo 4: Yazıcı'ya göre metin incelemesi için araştırma modeli (Tülek, 2017: 24):

\begin{tabular}{|c|c|}
\hline Parametreler & Değişkenler \\
\hline \multicolumn{2}{|l|}{ Yazar } \\
\hline \multicolumn{2}{|l|}{ Kaynak Adı } \\
\hline \multicolumn{2}{|l|}{ Yayın Yılı } \\
\hline \multicolumn{2}{|l|}{ Yayın Yeri } \\
\hline \multicolumn{2}{|l|}{ Dil } \\
\hline Erek Kitle & $\begin{array}{l}\text { Öğrenci, akademisyen, öğrenci adayı, profesyonel } \\
\text { çevirmen. }\end{array}$ \\
\hline Nitelik & Çeviri kuram, çeviri uygulama, çev. kuram+çev. Uygulama \\
\hline İnceleme Gereci & Ürün, süreç, ürün+süreç \\
\hline Çıkış Noktası & $\begin{array}{l}\text { Dilbilim, çeviribilim, dilbilim+çeviribilim, dilbilgisel } \\
\text { çözümleme }\end{array}$ \\
\hline Bilimsel Alan & Kuramsal, uygulama, uygulama+kuram \\
\hline Yöntem & $\begin{array}{l}\text { Betimleyici,açıklayıcı, betimleyici+açıklayıcı,örnekleyici, } \\
\text { açılayıcı+örnekleyici }\end{array}$ \\
\hline Anlıksal İşlemleme & $\begin{array}{l}\text { Tepeden aşağı, tabandan yukarı, tepeden aşağı + tabandan } \\
\text { yukarı, }\end{array}$ \\
\hline Ölçüt & Sözcük, tümce, sözcük+tümce+metin. \\
\hline Etki Alanı & Aktarım edinci, dil yetisi, çeviri edinci \\
\hline Kapsamı & Geniş kapsamlı, dar kapsamlı \\
\hline Çeviribilime Etkisi & Birincil dereceden etkinlik, ikincil dereceden etkinlik \\
\hline
\end{tabular}


Hatim ve Mason' un da bir metin çözümleme yöntemi geliştirdiklerini fakat bunu daha çok söylem analizi olarak adlandırdıklarını görmekteyiz. Çünkü çözümlemesi yapılanın aslında metin değil söylem olduğunu, metin ile söylemi, metnin salt dil ve biçimden oluşması, söylemin ise dil ve biçimin yanı sıra dil dışı ve metin dışı bağlantıların metin ile bütünleşmesiyle oluşması dolayısıyla ayırmakta ve önerdikleri bu çözümlemeyi "söylem çözümlemesi (Karşıtsal Söylem Çözümleme Modeli)" olarak adlandırmanın daha doğru olduğunu anlatmışlardır (Hatim, 1997). Hatim, söylem analizi amacıyla metin türlerini aşağıdaki şemadaki gibi üçe ayırmaktadır (Reiss'ın ayrımına benzer olarak) (Bulut, 2002;19, Aktaran Tülek, 2017:25):

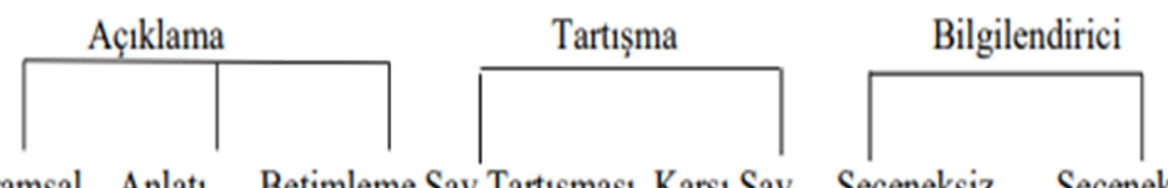

\section{Kavramsal Anlatı Betimleme Sav Tartıșması Karșı Sav Seçeneksiz Seçenekli}

Şekil 1: Hatim'e göre metin türleri ayrımı

Tablo 5: Hatim ve Mason'a göre metin biçimlerinin söylemsel açıdan sımıflandırılması (Bulut, 2002; 26, aktaran Tülek, 2017: 26):

Çok kutuplu

Melez

Belirli/belirsiz niyetli

Değerlendirmeye açı/kapalı

Tablo 6: Bulut’a (2002) göre metin çözümlemesi için sorulabilecek sorular (Tülek, 2017: 26):

1) Metin Açıklayıcı mı/ Tartışmacı mı/bilgilendirici mi/melez mi?

2) Açıklayıcı ise kavramsal açıklama mı/anlatı mı/betimleme mi?

3) Tartışma amaçlıysa bir savı savunuyor mu/ karşı mı çıkıyor?

4) Betimleyici veya açıklayıcı ise en özlü bilgi metni mi, açıklamaya, yorumlamaya mı yönelik, yoksa özet mi?

5) Bilgilendirici ise duruma/ kuruma mı bağlı, olay odaklı/değerlendirme gerektirmeyen mi, olaya odaklı değerlendirme gerektiren mi, kişi odaklı mı?

\section{3. Çeviri öncesi metin analizi yapma}

Çeviriye geçmeden çevirmenin yapacağı karmaşık analiz faktörleriyle başa çıkabilmek için kullanacağı diğer bir önemli faktör olarak dil (kaynak dil/ KD ve HD ) yetisi ve edimbilimsel yetiyle ilişkisine değinilecektir. Kansu-Yetkiner (2009) edimsel yetiyi çevirmende bulunan, uygun dil işlevlerini yerine getirebilmek için kullandığı bilgi birikimi olarak tanımlarken, bu yetinin ayrıca çevirmene faklı kültür ve dillerde değişiklik gösteren bağlama uygun dil işlevleri yerine getirme kurallarını gösterdiğini anlatmaktadır. Bu kurallar vasıtasıyla dil kullanımını belirleyen ilkelerin iki dilde benzeşmeyeceğini idrak etmiş olan çevirmenin "dil değişkelerine, kesit dil farklıklarına, kültürel gönderim ve algılamadaki çeşitliliğe” karşı dikkatli olması ve bilinçli adımlar atması beklenmektedir (KansuYetkiner, 2009: 42). Bu adımların ilki çevirmenin KD’de, edimbilimsel ve toplumdilbilimsel kurallar,

\footnotetext{
Adres $\mid$ Address

İstanbul Medeniyet Üniversitesi, Eğitim Bilimleri Fakültesi, Türkçe İstanbul Medeniyet University, Faculty of Education Sciences, ve Sosyal Bilimler Eğitimi Bölümü, Türkce Eğitimi ABD Cevizli Turkish and Social Scinces Education, Turkish Language Teaching Kampüsü, Kartal-İstanbul/TÜRKIYE $\quad$ Education, Cevizli Campus, Kartal-İstanbul /TURKEY e-posta: editor@rumelide.com 1 e-mail: editor@rumelide.com
} 
ilkeler konusunda bilgi sahibi olması ve bunların HD normlarına göre yeniden düzenlenmesini sağlayabilmesidir. Yani çeviri etkinliği, her şeyden önce metni yorumlayarak anlamayı ve daha sonra onu başka bir dilde yeniden ifade etmeyi gerektirecektir (Göktaş, 2014: 50). Bu bağlamda bir metinin analizinde salt dilbilimsel bileşenlerin inceleme aracı olarak kullanılmasının yeterli olamayacağı, aynı zamanda kaynak metindeki o topluma özgü kültürel, sosyal olguların çevirmen tarafından anlaşılması, yapacağı aktarımda kültürel yetisini devreye sokması beklenmektedir. Edimbilimsel olarak metnin işlevselliğinin oturup oturmadığına dair de bir inceleme süreci oluşturulmalıdır. $\mathrm{Bu}$ edimsel çözümleme süreci ile alakalı olarak Schaffner (2002) metni çevirmeden önce çevirmenin öncelikle KD yazarının sosyokültürel olarak belirli okur üzerinde yaratmayı hedeflediği etkiyi hangi dil yapıları ile kurguladığını anlaması gerektiğini savunmuştur. Erdmann ve diğerleri (1994) ise çeviri odaklı KD çözümlemesi ve çeviri öncesi metin çözümlemesinde çevirmenin mutlak amacının çeviri sürecinde HD’ye aktarım yaparken edibilimsel olarak sorun oluşturacak öğeleri saptaması gerektiği ve bu durumla baş edebilme stratejilerini ilgili çevirmen yetileriyle gerçekleştirme savını desteklemişlerdir.

\subsection{Sözlük ve internet kullanımı}

Teknolojinin hızla ilerlediği bu dönemde özellikle bilgisayar, android ve yapay zekâ teknolojilerinin geldiği nokta da hesaba katılırsa bilimsel gelişmelerin günümüzde geldiği seviye bilim insanlarının her gün donanımlarına ekleyeceği yeni bir teknoloji okur-yazarlığı gerektirmektedir. Profesyonel olarak çevirmenlik yapan kimselerden de bu bağlamda beklenen teknolojinin çeviribilim dünyası için sunduğu bu araçlardan gündemi takip ederek faydalanabilmek, yani yeni teknolojilerin okur-yazarı olabilmektir. Ersoy ve Balkul, teknoloji ve çevirmen ilişkisini inceledikleri araştırmalarında tam da bu noktanın önemine değinmiş, çevirmenlerin mesleklerine dair sürekli değişen ve gelişen bu teknolojik gelişmelerin takibini sıkı yapmadıkları sürece, gelişmelere uzak kalarak mesleki anlamda olumsuz etkilenebileceklerini belirtmişlerdir (Ersoy ve Balkul, 2012: 297).

Çevirmenler bu teknolojik hıza bir şekilde ayak uydurmak durumdadırlar ki bu boyuttaki yetilerini yeniden keşfedip güncelleyebilsinler. Bu da çevirmenlerde var olması gereken teknolojik/araçsal yeti kavramlarını ön plana çıkartmaktadır. Çevirmenin teknolojik yeti konusundaki işlevi yıllardır süregelen çevirmen portresi ve yetilerinde kaçınılmaz bir değişime yol açmıştır. Örneğin önceleri ağır sözlükler eşliğinde, daktiloyla çalışan çevirmen, günümüzde her türlü dijital ortamda ve araçla çalışabilen, çoğunlukla büyük bir ekibin parçası olarak farklı teknolojik yetilere sahip olmak zorundadır. Günümüzün çevirmenleri teknolojik yeti ile çeviri eylemini gerçekleştirirken eskisi gibi çok uzun saatler sözlük çalışması yapmaktan kurtulmuş, internetteki diğer yardımcı verilerle beraber çevrimiçi sözlükler, çeviri bellekler, çeviri programlar ile özel yardımcı ekipmanlarla çeviri eylemini büyük oranda bilgisayardan yapar hale gelmiştir (Ersoy ve Balkul, 2012: 298, Gürçağlar-Tahir, 2011: 61). Bir bakıma bilgisayarlar çevirmenlerin dijital ofisi haline gelmiştir. Ayrıca çevirmenlerin artık noter, adliye, tercüme bürolarına kısıtlı rollerden sıyrılarak küçük, büyük, ulusal veya uluslararası ölçekli kurum, şirket ya da devlet organlarında aldığı aktif grup içi çalışan(uzman) ya da son(post) editör rolü bu teknolojik değişimle güncellik kazanmıştır. Freigang ve Schmitz çevirmenin bu yeni rolü ile artık izole olmuş, yardım araçlarını ve yardım edecek kişileri kendisi bulmaya çalışan kişi olmadığını, organize olmuş bir ekibin içinde yer alan ve yardım araçları hazır bir şekilde kendisine sunulan birey durumunda olduğunu belirtmektedir (2002: 245-246). Teknolojik yetiyi artık çalışmalarının önemli bir parçaşı olarak kullanan uzman çevirmen, çeviriye yardımcı malzemeler olan çeviri bellekleri (Trados Translator's Workbench, Startransit ve Transit NXT, Dejavu ve IBM Translation Manager), elektronik bütünceler, terim bankaları, terminoloji yönetim sistemleri (Acronlinx, Anylexic, ApSICXbench, Interplex, I-term, SDL Multiterm, Termbases, TermWikiPro),

Adres

İstanbul Medeniyet Üniversitesi, Eğitim Bilimleri Fakültesi, Türkçe ve Sosyal Bilimler Eğitimi Bölümü, Türkce Eğitimi ABD Cevizli Kampüsü, Kartal-İstanbul/TÜRKIYE e-posta: editor@rumelide.com 
elektronik çevrimiçi sözlükler, çeviri yönetim sistemleri ve makine çeviri sistemlerini ve kendini sürekli güncelleyen benzer veri kaynaklarını etkin kullanmakla yükümlüdür (Köktürk, 2015: 45-75). Teknolojik yetinin çevirmene üstlendirdiği diğer bir rol yerelleştirme uzmanı rolüdür. "Bir ürünü bulunduğu kaynak kültürden satılacağı erek ortama dilsel ve kültürel olarak uygun şekilde aktarmak" (Esselink, 2000, Aktaran Köktürk, 2015: 75) olan yerelleştirme, en basit haliyle Microsoft gibi yazılımların her ülke diline göre aktarılması için çevrilmesidir. Dolayısıyla, bir dil ya da ülkeden diğer ülkelere tanıtılacak, aktarılacak ürün, yazılım, sanal veri vb. her şeyde yine bir fabrikada, şirkette vb. yerlerde bir ekip eşliğinde çalışan çevirmen ve devrede olan teknolojik yetilerini görmek artık çağın doğal gerekliliklerindendir. Özetle çevirmenin bu milenyumda edindiği özel roller, onları sürekli farklılaşan görevleri nedeniyle teknolojik yetilerini son kapasiteye kadar geliştirmeye ve kullanmaya itmektedir.

\subsection{Uzmanlara danışma}

Çevirmenler aktarım aşamasında ilerlerken, kavramsal olarak ya da kültürel olarak oturtamadığı kısımlarda iki yola başvurur; birincisi bu konuda hali hazırda çeviri yapan meslektaşlarına ikincisi ise KM' nin yazarına danışmaktır. Meslektaşlara veya KMnin yazarına danışma sürecini incelerken kuramsal olarak bu durumun Hölz-Mänttärri' nin Çeviri Eylemi Kuramında vurguladığı iş birliği kavramıla ilişkilendirilmesi makul sayılabilir (Holz-Mänttärri, 1984). Çünkü bu kurama göre çevirmen çevirinin merkezinde yer alan uzman olarak toplumsal ve iş birliğine dayalı bir eylem sürdürmekte, bilhassa meslektaşlarıyla yeri geldiğinde yardımlaşabilmektedir (Erkurt, 2014:121,122). Bu iş birliği KM' nin yazarına danışarak metinde özel açılıma ihtiyaç duyulan sözcük, öbek veya her türden konuyla alakalı olabilmekte veya bu çok mümkün görünmüyorsa benzer metinlerin çevirileriyle ilgilenen meslektaşlarla istişare edebilme de olabilir. KM’ ye benzerlik gösteren koşut metinlerin incelenmesi sonucu ulaşılan çıkarımlar da çevirmenin KM konusunda kültüral, semantik veya sentaktik analiz açısından doğru yol haritası çizmesini sağlayacaktır. Bu durum stratejik yetiyi çağrıştırmakla beraber çevirmenin yardım, iş birliği istemek için çeviri organlarıyla (meslektaşlarla, KM yazarıla) kurduğu bağlar ve etkileşim sosyal zekâ yetisi adıyla yeni bir çeviri yetisi olarak önerilebilir.

\subsection{Koşut metin ve alanla ilgili metinlerin analizi}

Yukarıda bahsettiğimiz ikinci konu olan çevirmenlerin aktarım aşamasına ilerlerken, kavramsal olarak veya kültürel olarak oturtamadığı kısımlarda başvurduğu ikinci yol, üretilecek HM ile aynı bağlamda olan diğer metinlere yani paralel/ koşut metin incelemesine başvurmaktır. En anlaşılır haliyle hukuk çevirisi yapan bir çevirmenin mahkemeye teslim etmekle yükümlü olduğu hukuki evrakın çevirisinde çözemediği kavram ve kısımları hukuk terimleri sözlüğü ile hukuk alanında arşivlenen ya da çalışılan salt hukuk metinlerinden yardım alarak çözmesi durumudur. Bu durum ise çevirmenin çeviri etkinliği süresince mantıklı yönde manevralar yapabilme ve karar verme kabiliyetlerine işaret ettiğinden stratejik yeti çerçevesi içine alınabilir.

\section{Hedef metni üretim sürecindeki beceriler}

HM' nin üretimi aşamasında çevirmenin izleyeceği yollar ve bu bilişsel süreçlere özel devreye sokması gereken bir takım yeti vardır. Şüphesiz ki en önemli ve çetrefilli aşamaya gelen çevirmen üretim aşamasında belli başlı engelleri aşarak çeviri icrasını gerçekleştirecektir. Çevirmenin ilk görevi, metni anlamak, analiz etmek ve o metin için uygun bir çeviri yöntemi seçmeden önce, metinle ilgili birkaç

\footnotetext{
Adres $\mid$ Address

İstanbul Medeniyet Üniversitesi, Eğitim Bilimleri Fakültesi, Türkçe İstanbul Medeniyet University, Faculty of Education Sciences, ve Sosyal Bilimler Eğitimi Bölümü, Türkce Eğitimi ABD Cevizli Turkish and Social Scinces Education, Turkish Language Teaching Kampüsü, Kartal-İstanbul/TÜRKIYE $\quad$ Education, Cevizli Campus, Kartal-İstanbul /TURKEY e-posta: editor@rumelide.com 1 e-mail: editor@rumelide.com
} 
genelleme yapmaktır ki burada çeviri teorisi devreye girer ve bu analiz için bazı kriterler ve öncelikler ortaya koyar (Özyön, 2014: 21)

\subsection{Kaynak metnin ve erek alıcının kültürel, dilsel taslağını oluşturma}

Kültür dediğimiz olgu "bir insan topluluğunun nesilden nesile aktardığı, gelenek halinde devam eden maddi ve manevi varlıklarının, değerlerinin bütünüdür (...). Topluluğun yaşayış ve davranış şeklidir” (Türkçe Sözlük, 2000: 621). Bu tanımlamadan kültür deyince hali hazırda bir aktarım olduğu görülür. "Bu aktarma işini üstlenen çevirmenin iki dili iyi bilmesi yeterli değildir, bu dili konuşan uygarlığı, kültürü tanıması gereklidir” (Aslan Karakul, 2015: 67). Dolayısıyla çevirmen iki koşulu eksiksiz yerine getirmelidir. Birincisi yabancı dili iyi öğrenmeli, ikincisi ise o dili kullanan topluluğun kültürünü iyi bilmelidir (Yalçın, 2003). Çevirmen bu hummalı aşamada öncelikli olarak KM' nin verdiği dilsel ve kültürel sinyallerden hedef alıcıya ait kültlere yönelik şemalar kurgulayacaktır. Erek alıcı dediğimizde akla ilk gelen erek alıcının kullandığı yabancı dil ve farklı bir kültürdür. Çevirmenin, yazarın içinde yaşadığı dönemi, o dönemin sosyokültürel yapısını, bu ortama uyumlu olup olmadığını iyi incelemesi gerekmektedir (Ladmiral, 1978: 161). Bu inceleme çevirmenin oynayacağı kültürlerarası arabulucu rolüne hazırlanırken iletişimsel, kültürel veya kültürlerarası yetisini kullanıma sokmasıyla başlar. Ana kültüründe var olan dilsel, sosyal, ekonomik vb. yönlerin tamamı HKnin aynı parçalarıyla etkileşerek, iki farklı kültürün benzerlikleri ve farklılıklarını tanımasını sağlayacaktır. Bu yönüyle Yücel, çeviri ediminin "etnososyolojik" bir düzlemde gerçekleşmesinden ötürü çevirmeni bazen yazınbilimci veya dilbilimci, bazen de bir kültür ve tarih araştırmacısı gibi çalışmaya ittiğini belirtmektedir (Yücel, 2007:107). Çevirmende bulunması gereken bu kültürel ya da başka bir değişle kültürlerarası yeti dilsel anlamın yanlış anlaşılmasından doğan eksikliklerin önlenmesinde önemli rol oynayacaktır. $\mathrm{Bu}$ eksiklikleri toplumedimbilimsel başarısızlıklar olarak tanımlayan Kansu-Yetkiner (2009) çevirmenin HD' nin sosyokültürel normlarını, uygun kesit dil kullanımını, incelik kurallarını ve tabu sözcüklerin kullanımını mutlaka dikkate alınması gerektiğini savunmuştur. Görüldüğü gibi dilsel taslağın kültürel öğeleri yanlış yorumlamaktan dolayı oturtulamaması ya da kültürel taslağın dilsel yapı ve dilbilimsel öğeleri yanlış yorumlayıp yanlış anlamlandırma kaynaklı kültürel taslağın oturtulamaması durumu çevirmeni kültürel ve dilsel yetilerini devreye sokamadığı sürece kısır bir döngüye sokacaktır. Dolayısıyla, birbirinden beslenen dilsel ve kültürel öğelerin ayrıntılı ve doğru çözümlenmesi, kaynak metnin taslağının doğru çıkarılması anlamına gelmektedir.

\subsection{Hedef metnin oluşturulması}

Yukarıda bahsedilen taslağın dilsel ve kültürel öğelerine ait doğru çözümleme sonrası çevirmen tarafından hazırlanan taslakla artık hedef metin oluşturulmaya başlanabilir. İşte tam bu süreçte, çevirmen yukarıdaki aşamalarda kullandığı yeti kümelerini en aktif ve bütüncül şekilde kullanma aşamasına girer. Parçalar giderek HM' yi oluşturmaya başlar ve erek metin hedef kitlede aynı işlevselliği sağlayacak dilsel, metinsel, kültürel öğelerle görünür kılınır. Karar verme süreçleriyle alakalı olan metinsel (metin türüne işlevine karar verebilme), kültürel (KM ve HK öğelerinin çeviride dengelenmesi) ve stratejik yeti bol miktarda kullanılır. Çevirmenin erek metni oluşturma sürecinde öncelikle kullanacağı metinsel yeti ile alakalı Reiss’in Metin Tipolojisi ve Çeviri Yöntemi (1976) adlı makalesi yol gösterici olabilir. Reiss her metin türüne özgü olarak çeviri ihtiyaç ve metodlarının türetilebileceğini savunmuş ve metinlerin tipolojisini analiz ederek metinleri dört sınıfa ayırmıştır. $\mathrm{Bu}$ metin türlerinden bağlamının kati surette korunması gerekenleri bilgilendirici metinler, daha çok biçimine ve biçemine ekstra önem vererek çevrilmesi gerekenlere "anlatımcı (dışavurumsal) metinler", aktarımda benzer etki sağlama yönünün ağır bastığı metinleri "işlemsel metinler” ve birkaç duyu

Adres

İstanbul Medeniyet Üniversitesi, Eğitim Bilimleri Fakültesi, Türkçe ve Sosyal Bilimler Eğitimi Bölümü, Türkçe Eğitimi ABD Cevizli Kampüsü, Kartal-İstanbul/TÜRKIYY e-posta: editor@rumelide.com
Address

Istanbul Medeniyet University, Faculty of Education Sciences,

Turkish and Social Scinces Education, Turkish Language Teaching

Education, Cevizli Campus, Kartal-İstanbul /TURKEY

e-mail: editor@rumelide.com 
organına hitap eden metinleri ise "çok araçlı metinler" olarak tanımlamıştır üzere dört başlık altında sinıflandırmıştır (Özyön, 2014: 20, 21). Böylece Reiss metin odaklı bir yöntemsel tasarım geliştirmiştir. Bu tasarıma göre çevirmen elindeki metni, bilgilendirici, anlatımcı ve işlemsel olorak üçe ayırabilir. Detaylara inecek olursak "ciddi edebiyat, yetkili beyanatlar ve kişisel, samimi dilde yazılar anlatımcı metinler grubuna dâhil edilebilir. Öte yandan, gazetecilik, raporlama, bilimsel ve teknik çalışmalar, genel ders kitapları, edebiyat dışı çalışmalar bilgilendirici metinler grubunda yer alırken; reklam, propaganda, tartışmalı çalışmalar, popüler edebiyat ayrıca okuru yönlendirme amaçlı tebliğler, yönergeler, kural ve düzenlemeler işlemsel metinler arasında sayılabilir” (Özyön, 2014: 23). Reiss bu metin odaklı çalışmasını çevirmenler HM' yi oluştururken yöntemlerini belirlemek için kullanabilirler. Aynı şekilde Newmark' ın metin analizi için çizdiği kriterler, HM' nin oluşturulması sürecinde çevirmene yol gösterebilir. Bu prensipler sırasıyla metnin amacı, çevirmenin amacı, okur ve metnin zamanı ile mekânı, yazının kalitesi ve metnin konuya hâkimiyetidir. Hem Reiss hem de Newmark' ın öne sürdüğü bu KM odaklı çeviri yaklaşımları HM' yi oluşturmada çevirmene sağlıklı bir bakış açısı sunarak, çeviri sürecinde bir dizi ilke ve kurallar önererek, kural koruyucu adeta onu denetleyici bir yönlendirmeyi amaçlar (Özyon, 2014: 21). Bu da çevirmenin HM’ yi oluşturmada ihtiyaç duyacağı yegâne yardımlardan bir tanesidir. Bu noktada çevirmenin ön plana çıkan yetileri metinsel, dilsel, kültürel, kültürlerarası yetiler yanında aktarım yetisi olacaktır.

\section{3. Çeviri sürecinin ve hatalarının gözden geçirilmesi}

Artık ortaya çıan HM' nin cümle yapıları, metin analizi, söylem analizi ve bu öğelerin alt başlıkları açısından hatalarla alakalı gözden geçirilecek hale gelmiştir. Bu gözden geçirme süreci ile alakalı bazı çeviribilimcilerin çeviri eleştirisinde kullandıkları ilkelerden, savlardan faydalanılabilinir. Örneğin Wilss'in (1982:220) eleştirmenlerce çeviride KM ve HM çakışmasını işlev-oluşturma, alımlama yönlerinden incelemesi gerektiğini aktarırken çeviri eleştirmeninin bu üç kriteri gerçekleştirmesini savunmaktadır: “önce kaynak ve erek metni karşllaştırmalı, ikinci olarak kaynak metne götüren ruhbilimsel süreçleri yeniden oluşturmalı ve üçüncü olarak da metinler arası yeterliliği ölçmek için bir formül geliştirmelidir”. Wills' in (1982) çeviri eleştirmeninden beklediği bu üç eylem çevirmenin kendisi tarafından yapılabilirse, çeviri çıtısı sonucu çevirmene yöneltilecek üst eleştirilerin göğüslenmesinde çevirmene katkı sağlayacaktır. Bu katkı çevirmen çeviri sürecini daha bitirmeden gözden geçirme yapmış olmasıdır. Eleştirel yanını kullanacak olan çevirmen, bu noktada yine metinsel, dilbilimsel ve bu alt alanları içeren burada önerdiğimiz eleştirel yetisini devreye sokacaktır.

\subsection{Hedef metnin düzeltilmesi}

Yapılan tüm bu araştırmalar sonucu eksikliklerin tamamlanması için yine bir çeviri eleştirisi çerçevesi olan Newmark' in (1988) eleştiri planı uygulanabilir. Çok teknik karşılanmamasına rağmen, aşağıda maddeleri sıralanan bu düzenlemeye göre kapsamlı bir çeviri eleştirisi beş konuyu içeririr (Newmark, 1988, 186-189):

“1. Kaynak metnin amaç ve işlevsel yönlerini vurgulayan kısa bir çözümleme.

2. Çevirmenin kaynak metnin amacı, çeviri yöntemi ve çevirinin hedeflenen okur

konusundaki yorumu.

3. Çevirinin özgün metinle seçmeli, ama yeterince ayrıntılı bir karşılaştırması.

4. Çevirinin a) çevirmen açısından, b)eleştirmen açısından değerlendirilmesi.

5. Uygun olursa çevirinin erek dil kültürü ya da disiplinindeki olası yerinin belirlenmesi”.

Adres

İstanbul Medeniyet Üniversitesi, Eğitim Bilimleri Fakültesi, Türkçe ve Sosyal Bilimler Eğitimi Bölümü, Türkçe Ĕ̆itimi ABD Cevizli Kampüsü, Kartal-İstanbul/TÜRKIYE e-posta: editor@rumelide.com
Address

Istanbul Medeniyet University, Faculty of Education Sciences,

Turkish and Social Scinces Education, Turkish Language Teaching

Education, Cevizli Campus, Kartal-İstanbul /TURKEY

e-mail: editor@rumelide.com 
Bu eleştiri maddeleri çevirmen tarafından hazırlanan HM düzeltme aşamasında kullanılırsa sağlıklı bir sonuç alınabilir.

\subsection{Hedef metnin yapısal olarak gözden geçirilmesi}

Bu bölümde çeviri eleştirisi için üretilmiş bir yaklaşımın oluşan HM üzerinde yapılacak son kontrol için kullanılmasının mümkün olacağı ileri sürülecektir. Yapılacak son kontrol yapısal olacağı için bu yönü ağır basan bir çeviri eleştirisi çerçevesine dikkat çekilecektir. House (1976) büyük ölçüde dilbilimsel ve kaynak odaklı bir yaklaşım olarak ürettiği modelinde çevirinin iki dil arasında, anlamı üç boyutta (anlam, edim ve metin), metinler arasındaki işlevsel eşdeğerliliğin önemine değinmekte; bunun iki metnin kullanım bağlamlarının belirlenmesiyle sağlanabileceğini öne sürmektedir. Bu modeldeki kullanım bağlamı Crystal ve Davy' den (1969) uyarlanan dil kullanıcısı ve dil kullanımı boyutlarının bileşenlerinden oluşturulmuştur. Bunlar arasında coğrafi kaynak, toplumsal katman, zaman ve dil kullanım ortamı, dili kullananlar, toplumsal rol ilişkileri, toplumsal tavır, konu alanı gibi ana öğeler bulunmaktadır. House tarafından ileri sürülen modelin işleyişi kısaca şöyle özetlenebilir: Önce KM yukarıda sözü edilen durum bağlamı bileşenleri açısından çözümlenecek ve böylece metnin sözcük, sözdizimi ve metin açısından bir profili çıkarılacaktır. Bu profil daha sonra HM' nin tanımlanması için bir ölçüt oluşturacaktır. House çevirinin değerlendirilmesinde bu karşılaştırma sırasında çıkan uyumsuzlukları da iki kümeye ayırmaktadır. İki metin arasındaki ayrımları örtük yanlışlar; metnin düz anlamının uyumsuzluğundan veya HD dizgesinin bozulmasından ileri gelenleri açık yanlış olarak adlandırılmaktadır. Bu açıdan HM' nin dilbilimsel son kontrolü için uygundur. Çevirmen bu modeli kullanarak dilbilimsel ve uygulamalı dilbilimsel (anadil- HD, diller arası) tüm bilişsel yetilerini bütünüyle devreye sokacaktır.

\section{Erek metnin çevirmenin işvereninden ve hedef kültürden aldığı karşılığın değerlendirilmesi}

HK' ye aktarımı sağlanmış, yayınlanmış, translatum haline gelmiş çeviri metin için yolun sonuna gelindiğini söylemek, modern betimleyici çeviribilim bakış açısna ters düşer. Bizim bu süreçteki önerimiz HM' nin ulaştığı okuyucu, yayınevi, eleştirmen tepkisinin algılanması ve diğer çevirilerde bu tepkilerden çıkarılacak derslere istinaden bir çeviri sürecine girebilmekle mümkündür. İşte bu farklı toplum kollarından gelen tepkinin çevirmence değerlendirilip anlamlı sonuçlar edinilmesi çevirmenin süreç sonrası performans değerlendirme yetisi olarak adlandırılabilir. Bu yeti işini iyi yapan, çeviri sürecinde yetilerine hâkim olan, sağlıklı bir eylem gerçekleştiren her çevirmenin sahip olması gereken bir yetidir. Aksi takdirde çevirmenin süreç boyunca faydalandığı yetileri yerini bulamayan çevirmen aldığı eğitimle uyuşmayan bir portre çizecektir. Bu durumda öncelikle çevirmenin farkındalığını HK alıcıları/okuyucuları üzerine yönlendirmesi, mümkün olduğunca alınan eleştirilerin, yorumların objektif bakış açısıyla değerlendirilmesi sağlanmalıdır. Çevirmene HM' den gelecek ikinci önemli tepki ise, çeviriyi talep eden yayınevi, kuruluş, işveren vb. gibi süreci başlatan tüzel ve özel kimselerin dönütleridir. Bu kimseler konumlarına göre nicel veriler eşliğinde çevirmene dönütler sağlamakla kalmaz, çevirmene piyasanın nabzını farklı bakışla tutabilen kimselerden öneri alabilmesini sağlar. Tabii çevirmenin zaman zaman gururlandırıcı ve bazı zamanlarda da acımasızca dönüt alabileceği merci eleştirmenlerdir. Eleştirmen yorumları çevirmenin gözden kaçırdığı her noktaya bir gönderme içerecek veya rahatlıkla üstesinden geldiği konulara ve yeti ilişkisine işı tutacaktır. Üç kategoride incelediğimiz bu dönüt ve eleştiriler çevirmenin benliğinde bazen yetersizlik, bazen zafer duygusuyla yer edecek; sonraki deneyimlerde kullanılmak üzere zihninin bir yerine kaydedilecektir.

Adres

İstanbul Medeniyet Üniversitesi, Eğitim Bilimleri Fakültesi, Türkçe ve Sosyal Bilimler Eğitimi Bölümü, Türkçe Eğitimi ABD Cevizli Kampüsü, Kartal-İstanbul/TÜRKIYE e-posta: editor@rumelide.com 


\section{Sonuç}

Akademik çeviri eğitiminin merkezi konusu olan çeviri yetisi ve de çevirmen yetisi konusunu ele aldığımız bu çalışmada, bu eylemi icra edecek çevirmenin yazılı çeviri sürecinin hangi basamağında hangi yetiyi kullanarak daha kaliteli bir çıktı elde edebileceği gösterilmeye çalışılmıştır. Ayrıca, araştırmaya özgü ana ve alt başlıklı Üç Aşamalı Aktif Çeviri Süreci ve Devredeki Çeviri Yetileri adıyla önerilen model, çeviri süreci ve bu süreç boyunca çevirmenin devreye soktuğu yeni yetileri aydınlatmaya, adlandırmaya odaklanmış ve çeviri eğitiminde yöntem gösterici ve kaliteyi artırmaya yönelik bir ders olarak sunulabileceği düşünülmüştür. Salt sezgi ve deneyimlere dayanılarak yapılmayan çeviri eyleminde ortak ölçütlere varabilmek ve bu deneyim ve yetilerin tekrar tekrar eğitilip güncellemek mümkündür. Çeviri eğitiminde belli bir kalite seviyesini yakalamak için oluşturulan bu yeti tabanlı ortak ölçütler konusunda farklı bilim kesimlerince farklı değerlendirilmesi olası olmakla beraber; bu değerlendirmelerden başka bakış açılarına varılması mümkün görünmektedir. Bu çalışmadan hareketle yapılacak ileriki araştırmalar çeviri sürecinde yeni çeviri yetilerinin keşfedilmesine bir zemin oluşturabilir. $\mathrm{Bu}$ yeni zemin ise donanımlı çevirmenler yetiştirebilmek için, yeti tabanlı çeviri ve çevirmen eğitiminde öğrencilere edindirilmesi hedeflenen birincil kazanımlar adıyla şekillenebilir. Yukarıda çeviri eğitiminde kullanılmak üzere bir ders olarak önerilen yeti odaklı model, çeviri eğitimi vasıtasıyla çeviri öğrencilerine hatta kendini güncellemek isteyen eğitimli veya eğitimsiz çevirmenlere aktarılabilir. Bu sayede çeviri mesleğine hâlihazırda adım atmış deneyimliler veya atacak olan öğrencilerin görevlerini gerçekleştireceği durumlarda bir çevirmende bulunması beklenen bilişsel, duyuşsal ve psikomotor donanımlara sahip olması ve bunu en yüksek seviyede nasıl kullanacaklarını kavramaları en güncel haliyle sağlanabilecektir.

\section{Kaynakça}

Adalı, O. (2003), Anlamak ve Anlatmak, 1.Baskı, Pan, İstanbul.

Albir, A. H. (2007). Competence-based curriculum design for training translators. The interpreter and translator trainer, 1(2), 163-195.

Akalın, R. (2016). Akademik Çeviri Eğitimi Açısından Çeviri Edinci Kavramı ve İçerimleri. Diyalog, 2016/2,56-65.

Aslan-Karakul, S. (2015). Çeviri Uğraşı. Turkish Studies International Periodical For The Languages, Literature and History of Turkish or Turkic,Volume 10/4, p. 63-78. DOI Number: http://dx.doi.org/10.7827/TurkishStudies.7931 ISSN: 1308-2140, ANKARA-TURKEY

Bachman, L. F. (1990). Fundamental Considerations in Language Testing. Oxford: Oxford University Press.

Birkan-Baydan, E. (2016). Çeviri Eğitiminde Çeviri / Çevirmenlik Edinci: Problem Çözme Ve Karar Verme Konusunda Bır Farkındalık Uygulaması. I.Ü.Çeviribilim Dergisi, 4 (7), 103-125. Retrieved from http://dergipark.gov.tr/iuceviri/issue/16998/177608

Canale, M., Swain, M. (1980). "Theoretical Bases of Communicative Approaches to Second Language Teaching and Testing”. Applied Linguistics, 1, 1-47.

Canale, M. (1983). “From Communicative Competence to Communicative Language Pedagogy”. In J.C. Richards \& R.W. Schmidt, (Ed). Language and Communication (pp.2-27). London:Longman.

Celce-Murcia, M. (2008). "Rethinking the Role of Communicative Competence in Language Teaching”. In E. A. Soler \& M.P. S. Jordà (Ed). Intercultural Language Use and Language Learning (pp. 41-57). Springer.

Celce-Murcia, M., Dörnyei, Z., Thurrell, S. (1995). "Communicative Competence: A Pedagogically Motivated Model with Content Specifications". Applied Linguistics, 6(2), 5-35

\footnotetext{
Adres $\mid$ Address

İstanbul Medeniyet Üniversitesi, Eğitim Bilimleri Fakültesi, Türkçe İstanbul Medeniyet University, Faculty of Education Sciences, ve Sosyal Bilimler Eğitimi Bölümü, Türkçe Eğitimi ABD Cevizli $\quad$ Turkish and Social Scinces Education, Turkish Language Teaching Kampüsü, Kartal-İstanbul/TÜRKIYE $\quad$ Education, Cevizli Campus, Kartal-İstanbul /TURKEY e-posta: editor@rumelide.com 1 e-mail: editor@rumelide.com
} 
Crystal, D., \& Davy, D. (1969). Investigating English style: David Crystal, Derek Davy. London, Indiana University Press.

Delisle, J. (2001) Analyse du discours comme méthode de traduction. Initiation à la traduction française de texte pragmatiques anglais (1982). Çeviri Yöntemleri İçin Söylem Çözümlemesi. (J. U. Derkunt Çev.). İstanbul: Marmara Üniversitesi. (1980).

Delisle, J. (1982). Analyse du discours comme méthode de traduction. Initiation à la traduction française de texte pragmatiques anglais, Théorie et pratique (2ème édition). Ottawa: Ed. De l'Université d'Ottawa.

Durukan, E. (2016). The Relevance of Translation-Focused Contrastive Grammar in the Acquisition of Basic Translation Skills / Çeviri Odaklı Karşılaştırmalı Dilbilgisinin Temel Çeviri Becerisi Edinimindeki Önemi Dil Eğitimi ve Araştırmaları Dergisi, 2(2), 41-52, Ağustos 2016 Journal of Language Education and Research, 2(2), 41-52, August 2016 http://dergipark.ulakbim.gov.tr/jlere/ Copyright (C) 2016 by JLERE ISSN: 2149-5602

Durmuşoğlu, G. (1991). Metin Dilbilim, Çeviri Süreci ve Çeviri Değerlendirmesi. Çeviribilim ve Uygulamaları Dergisi, sayı 1, 105-114.

Erkurt, G. Ş.(2014), Kişilik Ve Kültür Etkileşimi Bağlamında Çevirmen İdiokültürü'nün Çeviri Ürün Aracilığıla Erek Sosyal Yapıya Etkisi, Tarih Okulu Dergisi (TOD), Yll 7, Sayı XIX, ss. 23-46.

Ersoy, H., \& Balkul, H. (2012). Teknolojik gelişmelerin çevirmen ve çeviri mesleği açısından olumlu ve olumsuz etkileri: Çeviri alanında yeni yaklaşımlar. Akademik İncelemeler Dergisi, 7(2), 295307.

Eruz, S. (2004). Çeviri Bir Sanat Mıdır? Çevirmen Yetiştirme Sürecinde Akademik Çeviri Eğitimi. Internationales Übersetzungssymposium - ̈̈bersetzung- und Übersetzerprobleme. (Uluslararası Çeviri Sempozyumu -Günümüzde Çeviri ve Çevirmen Sorunları), 11-12 Ekim 2004, Sakarya Üniversitesi, Sakarya.

Eruz, S. (2003). Çeviriden Çeviribilime. İstanbul: Multilingual.

Göktaş, N. (2014). Yorumlayıcı çeviri kuramı'ndan çeviri eğitimine: Yorumlayıcı çeviri yöntemi. Diyalog Interkulturelle Zeitschrift Für Germanistik, 2(2), 46-60.

Hansen, G. (1999). Die Rolle der Fremdsprachlichen Kompetenz, Handbuch Translation içinde, Mary Snell-Hornby, Hans G. Hönig, Paul Kussmaul, Peter A. Schmitt,341-343. Tübingen: StauffenburgVerlag.

House, J. (1976) A Model for Translation Quahty Assessment. Tübingen: Gunter Narr Verlag.

Hymes, D. H. (1972). On Communicative Competence. J. B. Pride, J. Holmes, (Ed.) Sociolinguistics in (p. 269-93). Harmondsworth: Penguin Books.

Kansu-Yetkiner, N. (2009). Çeviribilim edinbilim ilişkisi üzerine. İzmir Ekonomi Üniversitesi.

Kautz, U. (2002). Handbuch Didaktik des Übersetzens und Dolmetschens. München: IudiciumVerlag.

Köktürk, Ş., \& Çoban, F. (2011). Çeviri Ve Anlama: Çeviride Anlamayı Etkileyen Faktörler.

Ladmiral, J.R. (1978). Traduction et Connotation. Dilbilim III, İstanbul: Üniversitesi.

Lederer, M. (1994). La traduction aujourd'hui, le modèle interprétatif. Paris: Hachette.

Lederer, M. (1987). "La théorie interprétative de la traduction". Le Français dans le monde. Recherches et applications, Août-eptembre 1987, no spécial, p.11-16, Paris.

Lederer, M. (1981). La traduction simultanée-fondements théoriques. Lettres Modernes. Paris: Minard.

Martinez Melis, N., \& Hurtado Albir, A. (2001). Assessment in translation studies: Research needs. Meta: journal des traducteurs/Meta: Translators' Journal, 46(2), 272-287.

\footnotetext{
Adres $\mid$ Address

İstanbul Medeniyet Üniversitesi, Eğitim Bilimleri Fakültesi, Türkçe İstanbul Medeniyet University, Faculty of Education Sciences, ve Sosyal Bilimler Eğitimi Bölümü, Türkce Eğitimi ABD Cevizli Turkish and Social Scinces Education, Turkish Language Teaching Kampüsü, Kartal-İstanbul/TÜRKIYY $\quad$ Education, Cevizli Campus, Kartal-İstanbul /TURKEY e-posta: editor@rumelide.com 1 e-mail: editor@rumelide.com
} 
Neubert, A. (2000). "Competence in Language, in Languages, and in Translation".). Schaffner, C. and Beverly A. Devetoping Translation Compelence (içinde). John Benjamins: Amsterdam, Philadelphia.

Newmark, P. (1988) A Textbook of Translation. Prentice Hail.

Özyön, A. (2014), Çeviri Sürecine Kaynak Metin Odaklı Yaklaşım - Source Text-Oriented Approach to Translation Process, IJLET (International Journal of Languages' Education and Teaching ), Volume 3, Issue 1, , p.17-24, ISSN:2198-4999.

PACTE (1998): "La competencia traductora y su aprendizaje: Objetivos, hipótesis y metodologia de un proyecto de investigación," IV Congrés Internacional sobre Traducció, Universitat Autònoma de Barcelona.

PACTE (2000). "Acquiring Translation Competence: Hypotheses and Methodological Problems of Research Project," Investigating Translation (A. Beeby, D. Ensinger and M. Presas, eds), Amsterdam, John Benjamins.

Şevik, N. \& Gündoğdu, M. (2018). Çeviri Eğitiminde Çevirmen Adayı Öğrencilerin Edinmesi Gereken Temel Becerilere Bir Üst Bakış. Ihlara Eğitim Araştırmaları Dergisi, 3(1), 78-89.

Yalçın, P. (2003) Jean-Louis Mattei'den Örneklerle Çeviride Kültürel Unsurlar Sorunu G.Ü. Gazi Eğitim Fakültesi Dergisi Cilt 23, Sayı 1 (2003) 47-58

Yücel, F. (2007). Tarihsel ve kuramsal açıdan çeviri edimi. Dost.

Vardar, B. (2007). Açılamah Dilbilim Terimleri Sözlüğü, Topkapı: İstanbul.

Wilss, W. (1982) The Science of Translation. Tübingen: Gunter Narr Verlag.

Zainnurrahman. (2010). Five Translation Competencies. Zainurahman's Personal Journal. 